\title{
A VÁROSOK SZEREPE A REGIONÁLIS FEJLŐDÉSBEN
}

\author{
Beszámoló a Magyar Regionális Tudományi Társaság \\ IV. vándorgyüléséről \\ (Szeged, 2006. október 26-27.)
}

\section{LUX GÁBOR - RÁCZ SZILÁRD}

A Társaság szegedi konferenciája aktuális szakmai témára, a városok térségi szerepére és problémáira fókuszált. A résztvevő 160 regionális szakember a városhálózat különböző szintjein vizsgálódva, hazai és határon túli példákon keresztül a városok társadalmi-gazdasági, valamint területi fejlődésre gyakorolt hatását kívánta megragadni.

A vándorgyülés programja a Társaság közgyủlésével indult. A köszöntők után sor került az új tagok felvételére, majd az elnökség és a tagozatok megtartották beszámolójukat. Horváth Gyula elnök hangsúlyozta, hogy a magyar regionális tudomány intézményesülésének szakasza lezárult, ennek befejező akkordja a Magyar Regionális Tudományi Társaság megszületése. A tagszervezés dinamikája 2006-ra (421fö) megállt, a jövőben a fiatal szakemberek körében célszerủ folytatni a tudományág népszerüsítését. Tagok lehetnek mindazok, akik érdeklödést mutatnak a terület- és településfejlesztés, a regionális politika iránt.

Kiemelkedő, hogy a regionális tagozatok a határon túl is megszerveződtek; Somorja, Komárom, Királyhelmec, Beregszász, Kolozsvár, Csíkszereda, Szabadka mủhelyeiben folynak területi kutatások. A regionális tudomány ilyen diffúziója intenzív határon túli és társtudományi kapcsolataival, új tudományos eredményeivel mintaként szolgálhat más tudományágak számára is. A szakma érdekérvényesítése folyamatosan fejlödik: tekintsük a területfejlesztési döntések előkészítésében való aktív közreműködését (NFT II, kiemelten ROP-ok véleményezése), a felsőoktatásban betöltött szerepét (új diszciplína, akkreditációk), a decentralizált államberendezkedés (mint a területi fejlödés jövője) melletti érvelését vagy növekvő publikációs teljesítményét ( 2 év alatt közel 80 regionális témájú könyv). A beszámoló lezárásaként az elnök vázolta a középtávú célkitüzéseket: esetleges szakmai tagozatok (ifjúsági, önkormányzati) önszervezödését, szorosabb együttmüködést a határon túli társaságokkal, fiatalok külföldi tanulmányútjainak támogatását, akadémiai regisztrációt (MTA szervezetkénti jövőt), nemzetközi konferencia szervezését (Pécs 2010), melyek lebonyolítása után érett szakaszába érhet az MRTT.

Varga Attila a nemzetközi kapcsolatokat emelte ki: a Társaság tagjai automatikusan ERSA tagok is, kedvezményes konferencia részvételi lehetöségük van az RSAI-nál, az ERSA 2008-as térökonómia témájú nyári egyetemét Pécsett rendezi. 
Tér és Társadalom 21. évf. 2007/1. 171-180. p.

A Társaság éves tevékenységének ismertetése után plenáris ülés következett. Felvezetöjében Enyedi György akadémikus hangsúlyozta a városok szerepét a gazdaság hálózatos fejlődésében. Magyarországon a város-vidék kapcsolatok meggyengülése okoz gondokat, miközben a globalizáció új kihívásokat támaszt irántuk: a városok a kreatív gazdaság terepeivé válnak, $\mathrm{s}$ ez olyan koncentrációval jár, amit a hagyományos eszközök nem képesek kezelni.

Lamperth Mónika miniszter az önkormányzati és területfejlesztési minisztérium új területfejlesztési stratégiáról tartott előadást. A következö években Magyarország csak lemaradásainak csökkentésében reménykedhet, $s$ már ez a feladat is az eszközök hatékonyabb felhasználását igényli. A hosszú távú stratégia a térségi versenyképesség erösítését és a területi felzárkóztatást, $\mathrm{s}$ az ország Európába történő területi integrációját tủzi ki; középtávon (2013-ig) a versenyképes közép-magyarországi centrumtérség és a hozzá kapcsolódó, városokra alapozott regionális fejlesztési pólusok megerősítése a feladat, miközben az elmaradott területeken a megerösített kistérségi központokra támaszkodó felzárkóztató fejlesztés célravezető. A hatékonyság kritériumai intézményi racionalizálást és forráskoncentrációt követelnek meg.

Szintén Budapest metropolisz szerepét és a kiegészítő pólusok jelentőségét hangsúlyozta Sára János az ÖTM föosztályvezetöje. A tudásalapú, versenyképes és innovatív társadalom fejlesztése erőforrás-koncentrációt igényel: konkrétabb akcióterületek meghatározását és a hálózatos kapcsolatok jobb figyelembevételét.

Pukli Péter a KSH elnöke a hivatal területi információs rendszerben betöltött szerepérỏl beszélt. A területi statisztikák iránti igények folyamatosan növekednek, egyszerre van szükség nagyobb adattömegre és finomabb monitoringra. A KSH legnagyobb feladata e téren a kiemelten „mély" adatigényü Urban Audit rendszeréhez történỏ csatlakozás.

Lukovich Tamás, a Magyar Urbanisztikai Társaság alelnöke a 21. század városversenyének sikertényezőjét az alkalmazkodási képességben és a lehetőségteremtésen alapuló szolidaritásban látja. A gazdasági fejlödésben korábbi soft tényezők válnak kemény versenyfeltételekké; elöretör a tudatos városképformálás, az újraéledt várostervezés és a városi terek új hasznosítása. Az új gazdaság hajtóereje a kreatív osztály: megteremtése magas minőségủ készségfejlesztést, megtartása színvonalas városi szolgáltatásokat követel.

Románia városfejlödési tendenciáit vizsgálta Benedek József kolozsvári egyetemi tanár. Románia történelmi öröksége az alacsony urbanizációs szint, az országban nyugati és keleti formák élnek együtt. 1990 után az urbanizációs színvonal csökkenése következett be, miközben várossá nyilvánítottak számos nem városias települést. Szerencsére a kitörés lehetőségeit kínálja a policentrikus nagyvároshálózat, ahol Erdély aránylag jó helyzetben van; ugyanakkor aggasztó a városok folytatódó etnikai homogenizációja, a magyarság részarányának 20,2\%-ra mérséklődése.

Faragó László, az MTA RKK föigazgató-helyettese részben a korábbi elöadásokra reflektálva az új (valójában ,retro”) területfejlesztési stratégiát is bírálat alá vette. Az EU területpolitikájában fokozódik a városok pozíciója; sőt, már-már egyenrangú a régió-politikával. Magyarországon hibásan, egymástól elválasztva kezelték a 
terület- (elsősorban vidék-) és településfejlesztést, $s$ az európai trendekkel ellentétesen az elöbbire helyezte a hangsúlyt. Az új stratégia megnyitná a lehetőséget egy modern várospolitika elött, annak ellenére, hogy Magyarország a főváros kivételével nem rendelkezik európai szinten is releváns városközpontokkal. Ezt a lehetőséget azonban csökkenti a fogalmi-koncepcionális zürzavar, a növekedési-versenyképességi-felzárkóztatási elemek elkülönítésének elmulasztása, miközben tisztább rendszerre, települési és térségi szempontok integrálására volna szükség.

A kisvárosok és városkörnyékek, vidéki térségek kapcsolatáról tartott előadást Csatári Bálint, az MTA RKK Alföldi Tudományos Intézetének igazgatója. A kisvárosok a vidéki tér rendezö-csomópontjai, versenyképességük forrása kedvező élőhelyi és tájképmegőrző szerepük. Magyarország kisvárosai nagymértékben elvesztették, vagy ki sem alakították térrendező szerepüket, s ezt elsősorban az elérhetőség fokozása, a tudatos perifériatámogatás - összességében pedig 100-120 kisváros „,kistafírozása" - orvosolhatja.

A legutolsó előadást Tosics Iván tartotta a városok társadalmi problémáiról. Bennük mind a lehetőségek, mind a problémák koncentrálódnak, s csak hagyományos és új technikák együttes alkalmazása, egy szociális és versenyképességi szempontokból is táplálkozó integrált stratégia kezelheti óket.

A vándorgyülés második napján öt szekcióban folytak az előadások. A társtudományokkal kialakult szerves kapcsolatot bizonyítja a területi statisztikusok önálló, városi információs rendszerek címmel rendezett szekciója. Az előadások fele az európai uniós városi statisztika, az Urban Audit adta lehetőségeket és kihívásokat demonstrálta, szó esett város és környéke kapcsolatának vizsgálatáról, valamint az Európai Városi Tudáshálózat kezdeményezéséről is (tapasztalatok megosztása, hatékony várospolitika). Az ülésen hirdették ki a területi statisztikai témájú Kovács Tibor-pályázat eredményét is.

A városhálózat magasabb szintủ egységeinek térszervező szerepéről szóló szekcióban számos elöadás konkrét régióhoz kötődött, egy részük a gyakorlati szempontok felöl közelített. A fővárosi agglomeráció közszolgáltatás-szervezésének problematikája felvetette a kérdést, együtt vagy külön kezelendö-e Budapest és Pest megye. A határon átnyúló kezdeményezések vizsgálatát - a Bécs vonzásán alapuló - osztrákmagyar térségi központok hálózati együttmüködésének tapasztalatai bővítették. A szakképzés és a területi versenyképesség összefüggései, a fenntartható településhálózat és szerkezet tovább árnyalta a nagyvárosi funkciókat.

A legnépesebb szekció témája a falu és város kapcsolatrendszer volt. A résztvevők között élénk és konstruktív vita bontakozott ki a kistelepülések jövőjét illetően. $\mathrm{Az}$ aprófalvak elnéptelenedése felvetette a település eutanázia gondolatát; fö ellenérvként a településsel együtt elvesző kultúrára hívták fel a figyelmet. Egyetértés mutatkozott abban, hogy a város mellett fontos a vidék is, hibás a kettöt elkülönítve kezelő fejlesztéspolitika. A kistérségi társulások müködése, a régi tanyarendszer funkcióváltása (falusi turizmus, szuburbanizáció) kézzel fogható eredményeket tár elénk. 
A városok társadalmi problémáit és a modern városi funkciókat bemutató szekciók igen sokfelöl közelítették meg a települések társadalmi és térkapcsolatait, ezek további kutatása és megismerése össztársadalmi érdek. Sokak véleménye szerint a dzsentrifikáció és a slumosodás új megközelítést igényel a várospolitikától. Az elöadók és a résztvevők is hangsúlyozták, hogy a települési és regionális versenyképesség javításában az egyetemek, üzleti inkubátorok és hálóztok szerepe kiemelkedỏ. Az elhangzottakat érdekes gondolatokkal színesítették a metrók terrorfenyegetettségéröl, illetve a bevásárlóközpontok beruházásaival kapcsolatos dilemmákról szóló előadások. Az előadások teljes anyaga olvasható a Társaság honlapján. http://www.mrtt.hu/ Az MRTT következö vándorgyülésére 2007 öszén, Miskolcon kerül sor, témája az ipar lesz. 